\title{
Stimulators and Inhibitors of Hepatic Porphyrin Formation in Human Sera
}

\author{
Arleen B. Rufkind, Shigeru Sassa, Irwin R. Merkatz, Robert Winchester, \\ Leonard Harber, and Attallah Kappas \\ From the Rockefeller University, New York 10021, the Department of \\ Obstetrics and Gynecology, Cornell University Medical College, New York 10021, \\ and the Department of Dermatology, New York University Medical School, \\ New York 10016
}

A B S T RACT Human sera were found to contain factors that stimulate and factors that inhibit porphyrin formation by cultured avian liver cells. The capacity of sera to stimulate or inhibit porphyrin formation varied in different hormonal states and in the porphyrias. Sera from 31 post partum women, eight of whom were not lactating, inhibited porphyrin formation to a mean level $30 \%$ below the level in control cultures and also inhibited drug and steroid stimulation of porphyrin formation. In contrast, mean porphyrin formation compared to control cultures was increased between 9 and $21 \%$ by sera from 52 normal subjects, 16 women on oral contraceptives, and 11 pregnant women. It was increased $193 \%$ by sera from nine subjects with acute intermittent porphyria and $172 \%$ by sera from 13 subjects with porphyria cutanea tarda. Heated sera or ethanol extracts of sera from all groups of subjects further increased the mean porphyrin stimulation by sera and, for the post partum subjects, eliminated the inhibitory effect. Ethanol extracts of sera from 28 oral contraceptive-treated women caused significantly greater mean stimulation of porphyrin formation than did extracts of sera from 30 normal women. While sera from 17 out of 22 porphyric subjects contained both stimulatory and inhibitory factors, 5 out of 22 had no evidence of an inhibitory component. There appeared to be heterogeneity in the occurrence of the factors among porphyrics.

The factor(s) in sera responsible for porphyrin stimulation were heat-stable and insensitive to trypsin; were present in the supernates after ethanol precipitation of plasma proteins; were extractable in ethyl acetate and nondialyzable; and they migrated with the albumincontaining fraction of serum during electrophoresis.

Received for publication 17 January 1973 and in revised form 19 July 1973.
The factor(s) responsible for porphyrin inhibition were heat labile, sensitive to trypsin, and resistant to neuraminidase; were present in the ethanol precipitates of sera and were nondialyzable; and they migrated with the gamma globulin fraction of serum during electrophoresis. Inhibition of porphyrin formation was not attributable to heme, free or bound as hemoglobin, hemopexin, or hemalbumin.

\section{INTRODUCTION}

Extracts of plasma from patients with acute intermittent porphyria (AIP) ${ }^{1}$ and from women ingesting oral contraceptive steroids have been found to stimulate porphyrin formation in cultured chick embryo liver cells (1). The chemical nature of the factor, or factors, in sera that increase the accumulation of porphyrins has not been identified. Among the many different drugs and steroids that have been shown to stimulate porphyrin formation, both in cultured liver cells and in animals and humans in vivo (2-9), steroid hormones and their metabolites are the only compounds occurring naturally in man. Well-documented variations in clinical activity of porphyria with respect to sex and endogenous hormonal alterations (10), and evidence of increased urinary excretion of steroids with the capacity to stimulate porphyrins in AIP $(11,12)$, make particularly interesting the possibility that circulating hormonal substances are involved in the pathogenesis of porphyria.

${ }^{1}$ Abbreviations used in this paper: AIA, allylisopropylacetamide; AIP, acute intermittent porphyria; ALA, $\delta$ aminolevulinic acid; ALAS, $\delta$-aminolevulinic acid synthetase; DDC, 3,5-diethyl-1,4-dihydrocollidine dicarboxylate; PCT, porphyria cutanea tarda. 
The present study was designed to examine the effects of sera from subjects in a variety of hormonal states on liver cell porphyrin accumulation, and to compare these to the effects of sera from normal and porphyric subjects. We found that human sera contain factors that stimulate and factors that inhibit porphyrin formation by liver cells. The amount and relative proportion of those factors vary in different hormonal states and in the porphyrias. This report describes these findings and our progress in separating and characterizing the serum components responsible for the stimulatory and inhibitory phenomena.

\section{METHODS}

Subjects and blood samples. The subjects studied included 52 normal men and women, 28 women ingesting oral contraceptive steroids, 11 pregnant women, 31 post partum women, nine patients with AIP, and 13 patients with porphyria cutanea tarda (PCT). The normal subjects were composed of two groups. The first group, designated "normal subjects A," consisted of 33 women between the ages of 20 and 35 who attended the obstetrics and gynecology clinic at The New York Hospital for routine examinations. Their sera and sera extracts were used for the data in Fig. 1. The second group, designated "normal subjects B," consisted of 11 women and eight men, between the ages of 21 and 35, who were laboratory personnel and volunteers for this study. Their sera were used for the data in Fig. 4. All normal subjects were healthy and denied having ingested any drugs within the month preceding the study.

The contraceptive-treated group consisted of 28 women, ages 18-38, attending the obstetrics and gynecology clinic at The New York Hospital. Each subject was taking the usually recommended doses of Ortho-novum (norethindrone and mestranol, Ortho Pharmaceutical Corp., Raritan, N. J.), Ovulen (ethynodiol diacetate and mestranol, G. D. Searle and Co., Chicago, I1l.), or Norlestrin (norethindrone acetate and ethinyl estradiol, Parke, Davis and Co., Detroit, Mich.). They had been taking the contraceptives from 3 to $30 \mathrm{mo}$.

The pregnant group consisted of 11 women, ages 23-32, attending the prenatal clinic at The New York Hospital. They were all between the 30th and 38th wk of gestation and, therefore, were all in the $3 r d$ trimester. Six were primigravidas and five were gravida twos.

Sera were obtained from 20 post partum women, 3-4 days after normal spontaneous deliveries at The New York Hospital. Most of the women selected (17 subjects) were lactating, thus excluding any effect from hormones given to suppress lactation. Sera from three nonlactating women were also examined. Blood samples were also obtained at routine examinations, 6 wk post partum, from 11 women, 6 of whom had breast fed their infants and five of whom had not. The post partum women were between 14- and $25-\mathrm{yr}$ old. Of the 31 subjects in this group, there were 17 primigravidas, 9 gravida twos, 2 gravida threes, and one each gravida four, five, and seven.

9 subjects with AIP and 13 with PCT were patients at the Rockefeller. University Hospital or University Hospital (New York University). Diagnoses were based on characteristic history, clinical observations, and measurements of urinary porphyrins and porphyrin precursors, ac- cording to the criteria described by Marver and Schmid (10). The AIP patients included one man and eight women, ranging in age from 22 to 56 . The PCT patients included nine men and four women; they ranged in age from 30 to 65. During the study, two AIP inpatients received meperidine for pain. The others with AIP and those with PCT had received no drugs within at least 1 mo before giving the serum samples.

Blood was drawn into tubes without anticoagulants. Clots were allowed to form for $2 \mathrm{~h}$, and then the samples were spun at $2,000 \mathrm{rpm}$ for $20 \mathrm{~min}$ at $4^{\circ} \mathrm{C}$. 2 - $\mathrm{ml}$ aliquots of sera were placed in glass vials and kept at $0^{\circ} \mathrm{C}$ until used.

Expcrimental mothods. Chick embryo liver cells were grown in primary cultures according to the method of Granick (2). In brief, livers from 14- or 15-day-old chick embryos were minced and then incubated at $37^{\circ} \mathrm{C}$ for $20-30$ $\min$ in $9 \mathrm{ml} 1 \%$ trypsin (Gallard-Schlesinger Chemical Mfg. Corp., Carle Place, N. Y.) and $3 \mathrm{ml} 1 \%$ pangestin (Difco Laboratories, Detroit, Mich.). Approximately $5 \times$ $10^{5}$ cells were added to $19 \times 65-\mathrm{mm}$ glass shell vials, in each of which a glass cover slip had been placed. Eagle's powdered basal medium (Grand Island Biological Co., Grand Island, N. Y.) in distilled water was supplemented per liter, as follows: $3.0 \mathrm{~g}$ sodium bicarbonate, $100 \mathrm{ml}$ fetal bovine serum (Microbiological Associates, Inc., Bethesda, Md.), $10 \mathrm{ml}$ amino acid concentrate (Microbiological Associates, Inc.), and antibiotics (streptomycin, $100 \mathrm{mg}$, penicillin, 100,000 U, and Mycostatin [E. R. Squibb and Sons, Princeton, N. J.], 25,000 U). $\mathrm{pH}$ was adjusted to 7.4. $1 \mathrm{ml}$ medium was added to each vial. The vials were incubated at $37^{\circ} \mathrm{C}$ in an atmosphere of $95 \%$ air and $5 \%$ $\mathrm{CO}_{2}$ for $24 \mathrm{~h}$, after which the media were replaced with fresh media, and additions to the vials (sera, extracts of sera, modified sera, drugs) were made. The vials were incubated for an additional $20-24 \mathrm{~h}$ and then frozen.

Porphyrins were measured by the method of Granick (2), modified by Sassa. The modifications involved lyophilizing the cells and media, measuring total porphyrin accumulation in the combined cells and media (rather than in the cells alone), and using an R-136 photomultiplier tube to enhance red-light sensitivity of the fluorimeter. Porphyrins were extracted from the lyophilized material by adding $5 \mathrm{ml}$ of a solution of $1 \mathrm{~N}$ perchloric acid: methanol $(1: 1, \mathrm{vol} / \mathrm{vol})$ to each vial in the dark, stirring on a Vortex mixer (Scientific Industries, Inc., Queens Village, N. Y.), and filtering through Whatman paper no. 2 after 30 min. Porphyrins were measured in the filtrate, using a Hitachi model MPF 2 A spectrophotofluorimeter (The Perkin-Elmer Corp., Norwalk, Conn.) at an excitation wave length of $400 \mathrm{~nm}$ and an emission wave length of 654 $\mathrm{nm}$. In some experiments, emission spectra from 560 to 700 $\mathrm{nm}$ were obtained to characterize the type of porphyrin formed. A coproporphyrin III reference standard was included in each assay to permit quantification of the porphyrins. Mean recovery of added coproporphyrin III was $90 \%$.

In control experiments, $100 \mu 1$ untreated or heated sera from normal, post partum, and porphyric individuals, (a) yielded no measurable porphyrins when incubated with media in the absence of cells $(b)$ did not produce any changes in porphyrin formation when added to cells at the end of the incubation period, and (c) did not interfere with the measurement of porphyrins. Therefore, the serum effects on liver cell porphyrin formation we observed could not be attributed to porphyrins in sera, to direct 
effects of sera on porphyrin formation, or to interference by sera with the extraction or measurement of porphyrins.

Two types of controls were routinely included in each culture experiment. The first was the inclusion of 10-15 vials to which no additions were made, based on our observation that $100 \mu \mathrm{l}$ of water, $0.9 \%$ saline, $0.1 \mathrm{M}$ phosphate buffer at $\mathrm{pH} 7.4$, Earle's balanced salt solution, and the residue of $10 \mathrm{ml}$ evaporated ethanol in $1 \mathrm{ml}$ water, added to $1 \mathrm{ml}$ medium, had no effect on porphyrin accumulation. The second control was the inclusion of 10-15 vials containing $30 \mu \mathrm{g}$ allylisopropylacetamide (AIA), a drug which is a known stimulator of porphyrin formation. The vials with AIA were included in each experiment, both to ensure that the cells were capable of increasing porphyrin formation in response to a drug and to allow measurement of the extent of responsiveness of each particular cell culture preparation. In early experiments we included several doses of AIA to construct AIA doseresponse curves but later used multiple vials with one standard dose of AIA $(30 \mu \mathrm{g})$ which we found equally effective for judging the responsiveness of each cell culture preparation.

Each cell culture preparation consisted of 150-250 vials, and the data reported here are derived from approximately 60 cell culture experiments. Each experimental group included five to ten replicate vials. The mean porphyrin accumulation in each group of replicate vials was calculated, as well as the $\mathrm{SE}, \mathrm{SD}$, and total variance.

Within each cell culture experiment, the mean variation between duplicate vials was small (about 10\%). There was, however, greater variation in responsiveness among separate cell culture experiments. For example, in 60 experiments, $30 \mu \mathrm{g}$ AIA resulted in porphyrin stimulation ranging from 5 to 33 times control values, with a mean value of 10 times control. To facilitate comparisons among responses of sera tested in different cell culture experiments, the data have been normalized as follows: the ratio between the observed response to AIA $(30 \mu \mathrm{g})$ and the average AIA response (10 times control) was derived; the experimental results were then multiplied by that ratio to obtain corrected results; the control values were taken as $100 \%$; and the percent increase or decrease in porphyrin formation after the addition of serum was calculated. For example, if control values were $5 \mathrm{pmol}$ porphyrin/vial, and AIA $(30 \mu \mathrm{g})$ resulted in porphyrin formation of 40 pmol/vial, the ratio, $[50$ (expected) -5 (control) $] /[40$ (observed) -5 (control) $]=1.29$, would be calculated. A hypothetical serum response of $12 \mathrm{pmol} / \mathrm{vial}$ would be multiplied by the factor, 1.29. The corrected result, 15.5, would be used to calculate the percent increase in porphyrin formation compared to controls. When the observed porphyrin stimulation by $30 \mu \mathrm{g}$ AIA exceeded 10 times control, the serum responses were correspondingly decreased by the correction procedure. For inhibitory effects of sera in cultures in which porphyrin formation was stimulated by AIA, the data were corrected as described above. For inhibitory effects in control cultures, no adjustments were made because the amount of inhibition of the already low porphyrin levels in control cultures could not be shown to be related to the induction response of the particular culture to AIA. Statistical significance of differences from the appropriate control and statistical significance of differences in mean responses of sera from different groups of subjects were determined by Student's $t$ test. Differences were accepted as being statistically significant if the $P$ value was $<0.05$.

The normalized data are presented for purposes of com- paring results from several cell culture experiments. We wish to emphasize, however, that the normalization procedure did not result in any qualitative or any statistically significant quantitative changes in the findings, since the mean results when calculated from the normalized data were, in no instance, significantly different from the results calculated from the raw data. The normalization procedure demonstrates that variations in responsiveness of cell culture preparations cannot account for the findings reported.

Six lots of fetal bovine sera were used in these experiments. Each lot had been pretested and accepted if it had no harmful effect on cell morphology and if it permitted at least a 10 -fold stimulation of porphyrin formation by $30 \mu \mathrm{g}$ AIA. There were no significant differences in the range of responses to AIA in cell cultures using the different lots of bovine sera. Moreover, sera from each group of subjects were examined with each lot of bovine sera, and the behavior of the sera remained true to type, i.e., extracts of sera from oral contraceptive-treated and porphyric subjects increased porphyrin accumulation, while post partum sera inhibited porphyrin formation, regardless of the lot of sera used. Sera from eight individuals were tested in cell culture experiments using two-four different lots of bovine sera. The mean difference in response was only $15 \% \pm 0.03$ (SE). Therefore, since different lots of fetal bovine sera did not introduce a major variable into the system, no adjustment was made for the different lots of fetal bovine sera. $100 \mu 1$ fetal bovine sera, an amount equivalent to the amount of human sera usually added to cultures, did not affect control or AIA-induced porphyrin formation. $100 \mu \mathrm{l}$ fetal bovine sera heated to $60^{\circ} \mathrm{C}$ for $10 \mathrm{~min}$ resulted in porphyrin formation 1.21 times the level in control cultures.

$\delta$-Aminolevulinic acid synthetase (ALAS) activity was measured in the mitochondrial subfractions from liver cells grown in 10-cm Petri dishes (Falcon Plastics, Div. of Bioquest, Oxnard, Calif.) containing 20 times the amount of media, cells, and sera used in the vials (13). Reactions were carried out in duplicate in incubation volumes of 200 $\mu 1$ and were stopped with $200 \mu 1 \quad 10 \%$ trichloroacetic acid. Each reaction mixture contained one-fifth of the mitochondrial $(10,000 \mathrm{~g})$ pellet derived from cells scraped together from two replicate Petri dishes. A zero-time control was always included. DNA was measured by the method of Kissane and Robins (14). Hemoglobin was measured by difference spectroscopy, using the method of Levere, Swerdlow, and Garavoy (15).

Ethanol extracts of sera were prepared by adding 10 vol of cold absolute ethanol to 1 or $2 \mathrm{ml}$ sera (1). After centrifugation at $2,000 \mathrm{rpm}$ for $10 \mathrm{~min}$, the ethanolic supernate was removed and the ethanol evaporated in vacuo at $37^{\circ} \mathrm{C}$. The dry residue was brought back to the original serum volume with Earle's balanced salt solution. It is this resolubilized dried ethanolic supernate that is referred to as "ethanol extract" in the text. Usually, $100 \mu \mathrm{l}$ sera, ethanol extracts of sera, or sera otherwise modified (see below) were added per culture vial.

To extract and partially purify the proteins precipitated by ethanol, the precipitates were extracted twice with 4 vol of $10 \%$ ammonium acetate in $70 \%$ ethanol. 2 vol of $10 \%$ ammonium acetate in $100 \%$ ethanol were added to the combined supernates, which were allowed to remain at $4^{\circ} \mathrm{C}$ overnight to reprecipitate the protein (16). The resulting fine precipitate was washed with ether, dried under air, and dissolved in a vol of Earle's balanced salt solution equal to the volume of the original serum sample.

For experiments examining the effect of neuraminidase 


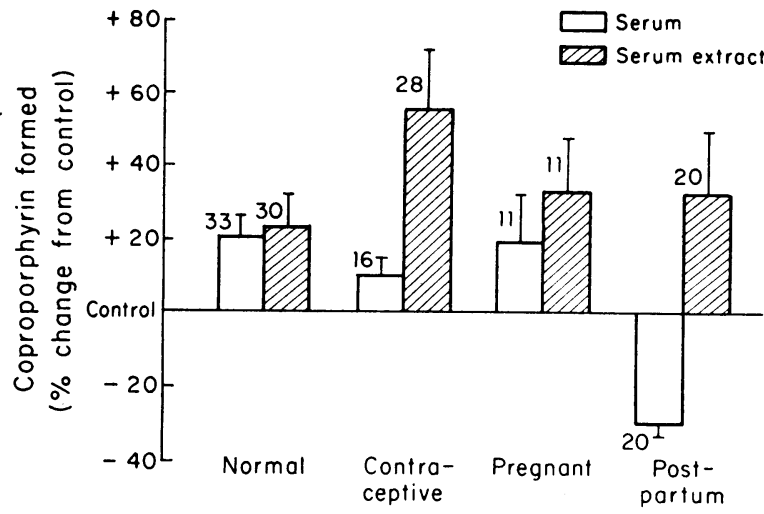

Figure 1 Effects of sera and sera extracts on coproporphyrin formation in liver cell cultures. The mean percent change in porphyrin formation compared to control cultures $(100 \%)$ is plotted for each group. The brackets enclose $1 \mathrm{SE}$. The numbers on top of each bar indicate the number of individuals from whom sera were obtained. $100 \mu \mathrm{l}$ sera or sera extracts were added per $1 \mathrm{ml}$ medium and cells, to each culture vial. Every serum sample or extract was tested in five replicate vials.

on serum modification of porphyrin formation, neuraminidase, (Vibrio cholerae, General Biochemicals Div., Mogul Corp., Chagrin Falls, Ohio) was added to Earle's balanced salt solution or to serum from a post partum woman, in concentrations of $1,2.5$, and $5 \mathrm{U} / \mathrm{ml}$, and incubated at $37^{\circ} \mathrm{C}$ for $30 \mathrm{~min}$. $\mathrm{pH}$ was adjusted to 5.6 during incubation and restored to 7.4 before addition of aliquots to culture vials. As a control, an aliquot of serum without neuraminidase was also incubated and subjected to $\mathrm{pH}$ change in the same way as the samples containing neuraminidase. AIA, $30 \mu \mathrm{g} / \mathrm{ml}$, was added to all culture vials. $0.1 \mathrm{ml}$ of the serum incubated, with or without neuraminidase, was added to each vial, and the effects on porphyrin formation measured as usual.

Preparative zone electrophoresis in $0.5 \mathrm{M}$ barbital buffer, $\mathrm{pH}$ 8.6, with Pevikon as supporting medium was performed according to the method of Müller-Eberhard (17). $5 \mathrm{ml}$ of serum was dialyzed against the buffer and applied. Electrophoresis was performed for $18 \mathrm{~h}$ at $4^{\circ} \mathrm{C}$. The block was divided into 17 1-inch strips, and each strip was then eluted with $0.15 \mathrm{M} \mathrm{NaCl}$. The eluates were dialyzed first overnight against $0.1 \mathrm{M}$ phosphate buffer, $\mathrm{pH} 7.4$, with two changes of the dialysis fluid, and then for $6-10 \mathrm{~h}$ in a $10 \%$ solution of polyethylene glycol to concentrate the specimens. Each fraction was brought to $5 \mathrm{ml}$ with Earle's solution. $100 \mu \mathrm{l}$ aliquots of the fractions treated in this manner were added to cultures. Protein contents of the fractions were measured by the method of Lowry, Rosebrough, Farr, and Randall (18).

\section{RESULTS}

Effects of sera and sera extracts on liver cell porphyrin formation. Fig. 1 shows the effects on liver cell porphyrin formation of $100 \mu 1$ sera and $100 \mu 1$ ethanol extracts of sera from normal women, women taking oral contraceptives, pregnant women, and post partum women. Sera from normal subjects A were used. Mean porphyrin formation $\pm \mathrm{SE}$, compared to control cultures by sera were as follows: 33 normals, $1.21 \pm 0.06 ; 16$ contraceptive-treated, $1.09 \pm 0.08 ; 11$ pregnant, $1.18 \pm$ $0.12 ; 20$ post partum, $0.70 \pm 0.04$. Thus, sera from normal, contraceptive-treated, and pregnant women caused a small stimulation of porphyrin formation, with no significant differences between the groups. In contrast, post partum sera inhibited porphyrin formation. The inhibition was statistically significant compared to all other groups at the $P<0.001$ level.

Mean porphyrin levels attained after the addition of ethanol extracts of sera from all groups of subjects were higher than the levels elicited by untreated sera. Mean porphyrin formation $\pm \mathrm{SE}$, compared to control cultures by ethanol extracts of sera, were as follows: 30 normals, $1.26 \pm 0.09 ; 28$ contraceptive-treated, $1.57 \pm$ $0.15 ; 11$ pregnant ; $1.37 \pm 0.10$; and 20 post partum, $1.36 \pm$ 0.15 . Mean porphyrin formation after the addition of ethanol extracts of sera from contraceptive-treated women was significantly higher than mean porphyrin formation after the addition of extracts from sera of normal women $(P<0.05)$. There were no significant correlations between the effects of sera on porphyrin formation and the time elapsed between drawing the blood sample and eating, day of the menstrual cycle. type of oral contraceptive used or the total length of time it was used, week of gestation, drugs given at or after delivery, nor parity of individual women.

Scra which inhibit porphyrin formation. Untreated sera from post partum women inhibited liver cell porphyrin formation in contrast to all other sera tested; but no inhibitory activity was evident in ethanol extracts of post partum sera. Porphyrin accumulation was decreased by sera from 17 out of 20 women, 3-4 days post partum. Sera from three nonlactating women inhibited porphyrin formation to a mean level $30 \%$ less than that of control cultures, as did the sera from lactating women.

Of the serum samples obtained from 11 mothers at the 6-wk post partum checkup, all inhibited porphyrin formation. Mean porphyrin formation in cultures to which sera from six lactating women were added was $0.73 \pm 0.03$ (SE) times the level in control cultures; while in cultures to which sera from five nonlactating women were added, the mean porphyrin accumulation was $0.71 \pm 0.03$ (SE) times the level in control cultures. Those levels were not significantly different from each other or from the mean inhibition by sera from women 3-4 days post partum. Menses had recurred in one subject; her serum was, nevertheless, also inhibitory. Thus, the capacity of sera to inhibit porphyrin formation persisted at least up to $6 \mathrm{wk}$ post partum, was not restricted to lactating women, and did not disappear with the onset of menses in one subject. 
TABLE I

Serum Inhibition of Porphyrin Formation Induced by Drugs and Steroids*

\begin{tabular}{lccc}
\hline \multicolumn{1}{c}{ Addition to culture vials } & $\begin{array}{c}\text { Number } \\
\text { of vials }\end{array}$ & $\begin{array}{c}\text { Coproporphyrin/ } \\
\text { vial } \pm \text { SE }\end{array}$ & $\begin{array}{c}\text { Inhibition } \\
\text { by serum }\end{array}$ \\
\hline & 15 & $11.0 \pm 0.7$ & $\%$ \\
None (control) & 11 & $5.1 \pm 0.2 \ddagger$ & -54 \\
Serum & 7 & $164.4 \pm 7.0$ & \\
AIA $30 \mu \mathrm{g}$ & 7 & $16.3 \pm 2.1 \ddagger$ & -90 \\
AIA $30 \mu \mathrm{g}+$ serum & 7 & $45.2 \pm 4.9$ & \\
Etiocholanolone $5 \mu \mathrm{g}$ & 7 & $8.0 \pm 0.3 \ddagger$ & -82 \\
Etiocholanolone $5 \mu \mathrm{g}+$ serum & 7 & $21.1 \pm 1.6$ & -77 \\
11-Ketopregnanolone $5 \mu \mathrm{g}$ & 7 & $4.8 \pm 0.6 \ddagger$ & -36 \\
11-Ketopregnanolone 5 $\mu \mathrm{g}+$ serum & 7 & $56.4 \pm 3.6$ & \\
DDC $10 \mu \mathrm{g}$ & 7 & $36.3 \pm 3.1 \S$ & -76 \\
DDC $10 \mu \mathrm{g}+$ serum & 7 & $43.2 \pm 2.4$ & \\
Secobarbital $20 \mu \mathrm{g}$ & 7 & $10.4 \pm 0.8 \ddagger$ & -88 \\
Secobarbital $20 \mu \mathrm{g}+$ serum & 7 & $124.0 \pm 31.2$ & \\
Mephenytoin $20 \mu \mathrm{g}$ & 7 & $14.3 \pm 0.2 \ddagger$ & \\
Mephenytoin $20 \mu \mathrm{g}+$ serum & & & \\
\end{tabular}

${ }^{*}$ Each culture vial contained $1 \mathrm{ml}$ medium and approximately $5 \times 10^{5}$ liver cells. Serum was always added in concentrations of $100 \mu \mathrm{l} /$ vial. All drugs resulted in significant stimulation of porphyrin formation compared to control cultures $(P<0.001)$.

$\$$ Significantly less porphyrin formation than in comparable cultures without serum $\ddagger(P<0.001)$, or $\S(P<0.05)$.

To amplify the inhibitory effect, $100 \mu \mathrm{l}$ post partum sera, together with $30 \mu \mathrm{g}$ AIA, were added to cultures. Mean porphyrin formation in cultures to which 23 post partum sera were added was $0.40 \pm 0.06$ (SE), while in cultures to which sera from 12 normal women were added, it was $0.91 \pm 0.08$ (SE) of the AIA-induced controls. The difference was significant at the $P<0.001$ level. Post partum sera also inhibited the stimulation of porphyrin formation by several different drugs and steroid hormones, including secobarbital (Seconal, Eli Lilly and Co., Indianapolis, Ind.), mephenytoin (Mesantoin, Sandoz Pharmaceuticals, East Hanover, N. J.), 3,5-diethyl-1,4-dihydrocollidine dicarboxylate (DDC), $5 \beta$-androstan-3 $\alpha$-ol-17-one (etiocholanolone) and $5 \beta$ androstan-3 $\alpha$-ol-11,20-dione (11-ketopregnanolone). The results of a characteristic experiment are shown in Table I.

The effect of sera which inhibited porphyrin formation on ALAS activity in liver cell cultures was measured (Table II). Compared to control cultures, sera from two post partum subjects, which had inhibited porphyrin formation by 54 and 32\%, depressed ALAS activity by 61 and $29 \%$, respectively, whereas a serum sample from a normal male that had not inhibited porphyrin formation did not inhibit ALAS. The depression of ALAS activity was not attributable to a direct inhibitory effect of the sera on ALAS, since the same sera added to chick embryo liver homogenates in vitro did not alter the activity of control or drug-induced ALAS.
When $5 \mu \mathrm{g} \delta$-aminolevulinic acid (ALA) was added to the culture vials, a mean increase of porphyrins to 20 times the level in control cultures resulted. Sera from eight post partum subjects caused a mean inhibition of conversion of $5 \mu \mathrm{g} \mathrm{ALA}$ to porphyrins of $34 \% \pm 0.06$ (SE). Sera from the same eight subjects inhibited the induction of porphyrin formation by $30 \mu \mathrm{g}$ AIA, by $55 \% \pm 0.06(\mathrm{SE})$. The decrease in AIA induction was significantly greater than the decrease in ALA conversion $(P<0.05)$.

\section{TABLE II}

Effects of Post Partum Sera on ALAS Activity in Cultured Liver Cells

\begin{tabular}{cc}
\hline Additions to cultures* & ALAS activity \\
\hline & $\begin{array}{c}\text { pmol } A L A \text { formed/ } \\
\text { Mg } D N A \text { per } h\end{array}$ \\
Experiment 1 & $32.7 \ddagger$ \\
None (control) & 12.7 \\
Post partum serum A & 30.3 \\
Normal male serum & \\
Experiment 2 & 30.4 \\
None (control) & 21.8 \\
Post partum serum B & \\
\hline
\end{tabular}

* Serum was added to Petri dishes containing $20 \mathrm{ml}$ media and approximately $10^{7}$ liver cells in a concentration of $0.1 \mathrm{ml} / \mathrm{ml}$ medium.

$\ddagger$ Each result is the mean of duplicate determinations on liver cells from two Petri dishes. 


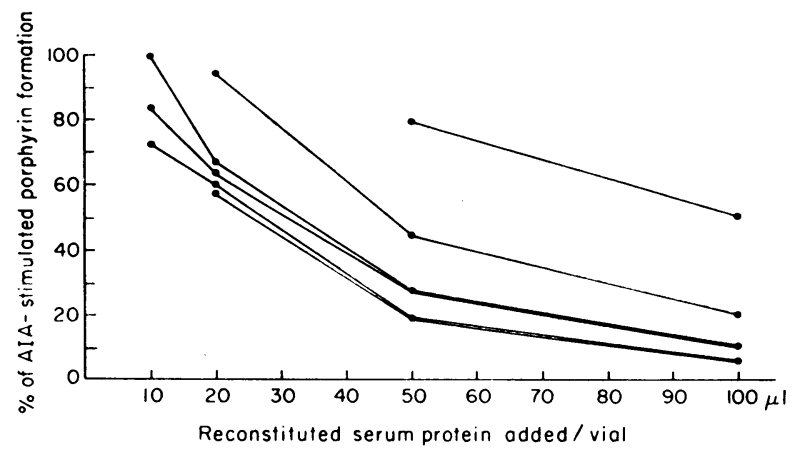

FIGURE 2 Dose-related increases in the inhibition of porphyrin formation by post partum sera. Proteins in serum samples from six post partum women were precipitated with ethanol, extracted, and then reprecipitated and dissolved in a volume of Earle's balanced salt solution equal to the original serum sample (see Methods) and added to cultures in the amounts indicated, with $30 \mu \mathrm{g}$ AIA. Porphyrins in the cells and media were measured $24 \mathrm{~h}$ later. The percent inhibition compared to AIA-induced controls $(100 \%)$ is shown. Each point represents the mean value from five replicate vials.

Recovery of inhibitory activity in precipitates after ethanol extraction of sera. Since inhibition of porphyrin accumulation was not evident in the ethanol extracts after precipitation of plasma proteins, an attempt was made to recover inhibitory activity in the ethanol precipitates. The precipitates were extracted, reprecipitated, and then dissolved in Earle's balanced salt solution, before being added to the cell culture preparations (see Methods). In six post partum serum samples, inhibitory activity was present in the whole serum and in the ethanol precipitates after partial purification and resolubilization, while it was absent in the ethanolic supernates. Recovery of inhibitory activity in the precipitates after ethanol extraction gave further evidence that the factor ${ }^{2}$ responsible for the inhibition probably was a protein or a substance tightly bound to a protein and, in light of the procedure used, suggested that it might be a glycoprotein.

Fig. 2 shows dose-response relationships between the amount of extracted serum protein added to the cultures and the degree of inhibition of AIA-stimulated porphyrin formation. Inhibitory effects were dose related. While the amount of inhibitory activity in different sera varied, dose-response relationships were parallel.

Heat and trypsin inactivation of inhibitory activity in serum; effect of neuraminidase. When sera from the post partum women were heated to $60^{\circ} \mathrm{C}$ for $10 \mathrm{~min}$ or

\footnotetext{
${ }^{2}$ We recognize that one or more than one factor may be responsible for inhibition of porphyrin formation and, likewise, for stimulation of porphyrin formation. For simplicity, however, we use the terms "factor," "component," and "substance" in the singular throughout the paper.
}

preincubated at $37^{\circ} \mathrm{C}$ with $0.1 \%$ trypsin for $30 \mathrm{~min}$, they no longer gave any evidence of inhibiting porphyrin formation. $0.1 \%$ trypsin in Earle's balanced salt solution or water did not affect porphyrin formation when added to cultures alone. The loss of inhibition by heating to $60^{\circ} \mathrm{C}$ for $10 \mathrm{~min}$ indicated that the inhibitor was heat labile and, therefore, most likely to be a globulin rather than albumin, which is not destroyed at $60^{\circ} \mathrm{C}$.

When inhibitory activity was reduced or eliminated by heating, the sera increased the accumulation of porphyrins by the cultured liver cells, as compared to control cultures, indicating that something in the unheated serum had masked the presence of a heat-stable substance capable of stimulating porphyrin formation. When sera were preincubated with trypsin, there resulted even greater enhancement of porphyrin stimulation than that caused by heating. The effects of heating and trypsin preincubation of a post partum serum sample on AIA-induced porphyrin formation are shown in Fig. 3. Similar effects occurred with other post partum serum samples, both in cultures to which no inducing

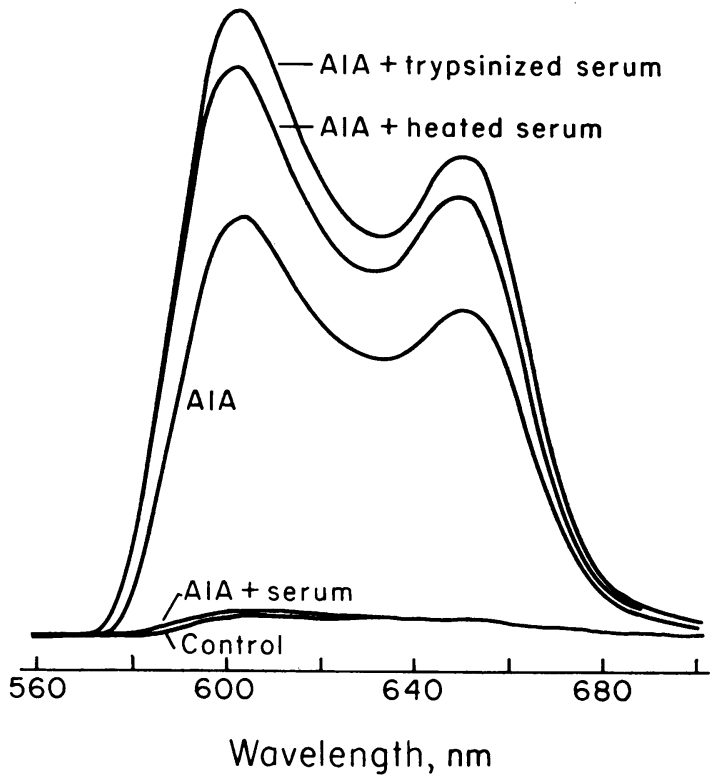

FIGURE 3 Reduction of inhibition of porphyrin formation in post partum serum by heating or trypsin preincubation. The fluorescence emission spectra from 560 to $700 \mathrm{~nm}$ of liver cell porphyrins are shown (excitation wave length, $400 \mathrm{~nm}$ ). The middle curve shows the spectrum from cultures treated with $30 \mu \mathrm{g}$ AIA. The two lower curves show the spectra from cultures to which AIA and serum (100 $\mu 1$ ) or no additions were made (control cultures). The addition of serum together with AIA resulted in inhibition of porphyrin formation nearly to control levels. The upper two curves show the effects on AIA stimulation of porphyrin formation, of the same serum heated to $60^{\circ} \mathrm{C}$ for ten $\mathrm{min}$, and preincubated with $0.1 \%$ trypsin for $30 \mathrm{~min}$ at $37^{\circ} \mathrm{C}$ 


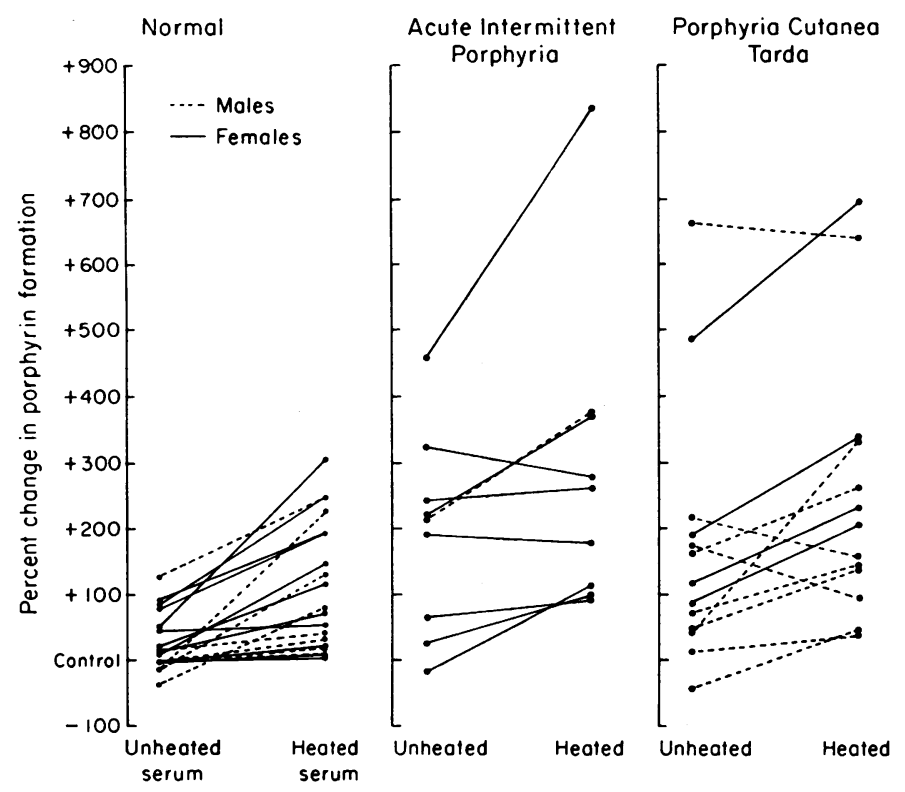

FIGURE 4 Effects of sera and heated sera from normal and porphyric subjects on porphyrin formation in liver cell cultures. The percent change from porphyrin formation in control cultures $(100 \%)$ after addition of $100 \mu \mathrm{l}$ sera or $100 \mu \mathrm{l}$ sera heated to $60^{\circ} \mathrm{C}$ for $10 \mathrm{~min}$ are shown. Each line connects points representing the mean porphyrin formation after the addition to cultures of unheated or heated serum from a single individual, derived from five replicate vials. Subjects included 19 normal men and women, nine patients with AIP, and 13 patients with PCT.

drug was added and in those in which porphyrin formation was increased by AIA.

In order to find out whether an intact glycoprotein was required for the inhibition of porphyrin formation by sera, the effect of neuraminidase on serum inhibition of porphyrin formation was examined. Neuraminidase at $1,2.5$, and $5 \mathrm{U} / \mathrm{ml}$ had no effect on the inhibition of porphyrin formation by sera. Since $0.5 \mathrm{U} / \mathrm{ml}$ has been reported to result in $100 \%$ desialyation of $30 \mathrm{mg}$ human chorionic gonadotropin (19), the concentrations of neuraminidase used in our experiments should have been adequate to indicate neuraminidase sensitivity. The inhibitory factor was, therefore, resistant to neuraminidase. Moreover, $N$-acetylneuraminic acid at 1,10 , and $100 \mu \mathrm{g} / \mathrm{vial}$ did not inhibit control or AIA-stimulated porphyrin formation. Though this evidence does not exclude the possibility that the inhibitor may be a glycoprotein, it suggests that an intact carbohydrate moiety is not essential for the inhibitory effect.

Exclusion of heme or a known heme-binding protein as the factor responsible for inhibitory activity. Heme is the only known substance normally present in human tissue that can inhibit porphyrin formation by liver cells. Since the inhibitor was destroyed by heating, and heme is heat stable, the inhibitor could not be heme. However, since heme commonly circulates bound to protein as hemoglobin, hemopexin, or hemalbumin, we consid- ered the possibility that the inhibitor was protein-bound heme. Hemoglobin and hemopexin ${ }^{8}$ contents of inhibitory sera were no higher than those of noninhibitory sera. Moreover, the inhibitor was inactivated at $60^{\circ} \mathrm{C}$, while albumin is not, and inhibitory activity was localized in the gamma globulin region of plasma, while the albumin region contained stimulatory activity. Therefore, the inhibitor does not appear to be heme bound to protein as hemoglobin, hemopexin, or hemalbumin.

Stimulatory and inhibitory activity in normal and porphyric sera. The reduction of the inhibitory activity in post partum sera by heating led us to reexamine the distribution of stimulatory and inhibitory activity in normal and porphyric sera.

The effects on porphyrin formation of $100 \mu l$ unheated sera and sera heated to $60^{\circ} \mathrm{C}$ for $10 \mathrm{~min}$, taken from nine subjects with AIP and 13 with PCT, are compared to the effects of sera from 19 normal subjects, in Fig. 4. Normal subjects $B$ were used in these experiments. Mean porphyrin formation $\pm \mathrm{SE}$, compared to control cultures resulting from the addition to cultures of unheated and heated sera from the three groups, are as follows : 19 normal men and women, $1.26 \pm 0.11,2.20 \pm$ $0.24 ; 9$ patients with AIP, $2.93 \pm 0.50,3.85 \pm 0.80 ; 13$ patients with PCT, $2.72 \pm 0.55,3.52 \pm 0.58$.

${ }^{\circ}$ Hemopexin was kindly measured by Dr. Ursula MüllerEberhard. 


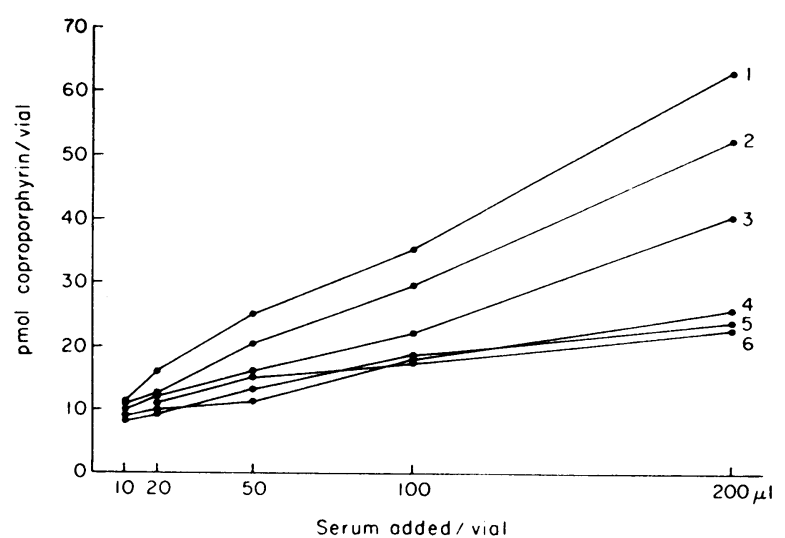

FIGURE 5 Dose-related increases in stimulation of porphyrin formation by sera. Sera from six subjects, $(1,2,3$, PCT ; 4, AIP ; 5, pregnant; 6, normal female), were heated to $60^{\circ} \mathrm{C}$ for $10 \mathrm{~min}$ and then added to culture vials in the amounts indicated. Porphyrin accumulation in the cells and media were measured $24 \mathrm{~h}$ later. Each point represents the mean value for five replicate vials. Mean porphyrin formation in 17 control vials (no added sera) was $6.29 \pm 0.54$ (pmol coproporphyrin $\pm 2 \mathrm{SE}$ ).

In all 19 normal subjects, heated sera produced higher levels of porphyrins than unheated sera; in 14 out of 19 the stimulation was statistically significant. There was no significant difference between the effects of sera from males and females. Thus, sera from normal individuals appeared to contain a component that inhibited and a component that stimulated porphyrin formation; heating reduced the inhibition and resulted in the dis. play of stimulatory activity.

Untreated sera from patients with AIP and PCT caused greater mean stimulation of porphyrin formation than did heated sera from normal subjects; and heating of AIP and PCT sera caused a further increase in mean porphyrin accumulation. In 5 out of 9 subjects with AIP, and in 5 out of 13 subjects with PCT, greater stimulatory activity than that found in sera of any normal individual was present in unheated sera. Sera from the other porphyric subjects could not be distinguished from normal sera. Both the AIP subject and the PCT subject whose sera had the greatest ability to stimulate porphyrin formation were clinically symptomatic. However, among the remaining subjects, no correlation was observed between symptoms and the capacity of serum to stimulate porphyrin accumulation. No effects could be attributed to meperidine in this small sample.

Heating did not increase the capacity to stimulate porphyrin accumulation in the sera from two subjects with AIP and one with PCT. Heating sera from two other patients with PCT resulted in significantly decreased stimulation of porphyrin formation, suggesting that in certain individuals with porphyria, the inhibitory component may be mssing, and moreover, that in some porphyrics the factor responsible for stimulation of porphyrin formation may also be partly heat labile.

To examine the dose-response relationships of the stimulatory effect, sera from six individuals (one normal, one pregnant, one with AIP, and three with PCT) were heated to $60^{\circ} \mathrm{C}$ for $10 \mathrm{~min}$ to inactivate the inhibitory component, and aliquots from 10 to $200 \mu 1$ were added to culture vials. The resulting dose-response relationships are shown in Fig. 5. Adding increasing amounts of heated serum to cultures resulted in increasing porphyrin formation.

Sera from two subjects with AIP were separately extracted with three organic solvents: ethyl acetate, dichloromethane, and petroleum ether. The stimulatory activities in both sera were fully extractable in ethyl acetate and not extractable in dichloromethane or petroleum ether, suggesting that polar compounds were responsible for the stimulation of porphyrin formation by the sera.

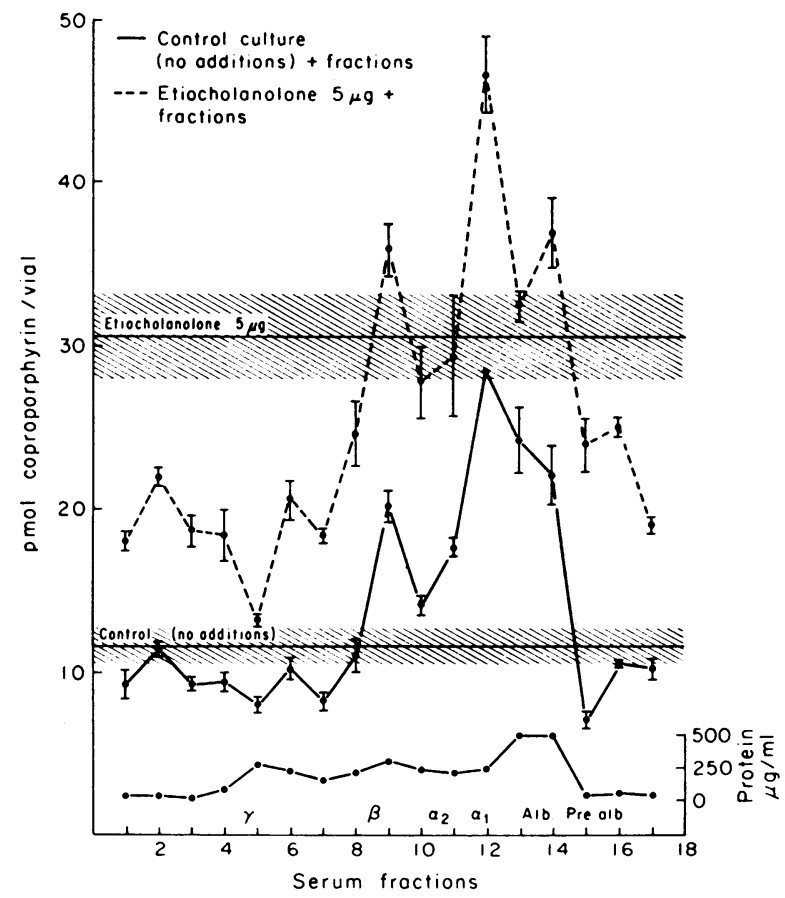

Figure 6 Separation by electrophoresis of the serum components responsible for inhibition and stimulation of porphyrin formation. Each point on the upper two graphs indicates the mean porphyrin formation in five vials to each of which $100 \mu \mathrm{l}$ of one of the serum fractions derived from electrophoresis was added. The brackets and the shaded areas define $\pm 2 \mathrm{SE}$. The bottom graph indicates the protein content of the fractions. Inhibitory activity is evident in the gamma region and stimulatory activity in the albumin region. 
Separation of the serum stimulatory and inhibitory factors. An attempt was made to separate the serum components responsible for stimulation and inhibition of porphyrin formation by zone electrophoresis. A serum sample from a post partum woman which caused pronounced inhibition of porphyrin accumulation when untreated and strong stimulation of porphyrin accumulation when heated, was used. After dialysis, the effects of 17 serum fractions on liver cell porphyrin formation were examined both in control cultures and in cultures in which porphyrin formation was stimulated by etiocholanolone. Additional controls contained dialyzed barbital buffer. The electrophoresis procedure effectively separated the stimulatory and inhibitory activities. Stimulatory activity was located in the albumin region and inhibitory activity in the gamma region; both zones were broad (Fig. 6). Moreover, since stimulatory and inhibitory activities were both evident after exhaustive dialysis, the responsible factors were not dialyzable.

The effects on porphyrin formation of dilutions of whole serum were compared to the effects of dilutions of the gamma globulin fraction which contained the inhibitory activity (Fig. 7). As the concentration of whole serum. was diluted by adding decreasing amounts of serum to a constant volume of medium, the inhibitory activity declined, and stimulatory activity became apparent. However, when the fractions which inhibited porphyrin formation were progressively diluted, the inhibitory effect diminished, but no stimulation was observed. Moreover, while heated whole serum stimulated the formation of porphyrins, the heated fractions containing the inhibitory activity did not; the inhibitory effect was merely diminished. Thus, gel electrophoresis had separated the two components, and the inhibitory

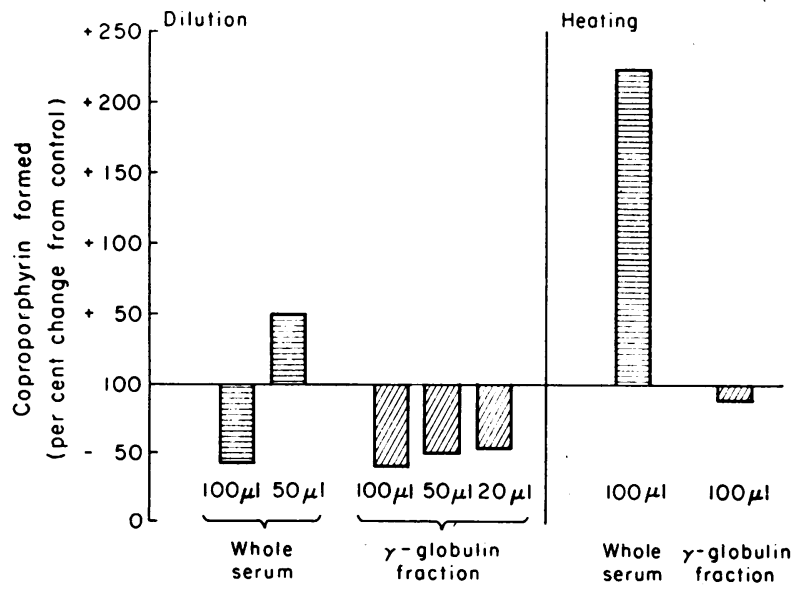

FIGURE 7 Effects of diluting and heating both serum and the inhibitory fractions derived from electrophoresis (gamma region) on porphyrin formation. Each result represents the mean effect from five replicate vials. The effects of dilution are shown on the left, and of heating, on the right. component gave no evidence of contamination with stimulatory activity.

Stability of factors. Serum inhibitory and stimulatory activities were unaltered after three repeated cycles of freezing and thawing, and remained stable at $0^{\circ} \mathrm{C}$ for at least $1 \mathrm{yr}$.

\section{DISCUSSION}

These studies show that human sera contain separable factors which respectively stimulate and inhibit porphyrin formation in cultured chick embryo liver cells. The factor responsible for porphyrin stimulation in most sera was heat stable, insensitive to trypsin, present in supernates after ethanol precipitation of plasma proteins, absent in the precipitates, extractable in ethyl acetate, not extractable in less polar organic solvents, not dialyzable, and migratory with the albumin fraction of serum on electrophoresis. The factor responsible for inhibitory activity was heat labile, sensitive to trypsin, resistant to neuraminidase, present in the precipitates after ethanol precipitation of serum proteins, absent in the supernates, nondialyzable, and migratory with the gamma fraction of serum on electrophoresis. The stimulatory component does not appear to be a protein, unless it is a protein that is soluble in ethanol and insensitive to trypsin. However, since the stimulatory component was present in the albumin fraction after electrophoresis and could not be dialyzed, it is probably normally bound to a serum protein. Since ethanol extracts as well as the albumin-containing fraction of sera stimulated porphyrin formation, the factor responsible for the stimulation may be active either in the free or protein-bound state.

Strand and Marver (20) reported that normal serum acquired the capacity to stimulate porphyrin formation after $\beta$-glucuronidase hydrolysis, indicating that substances in sera which stimulate porphyrins may be conjugated to glucuronic acid and that the stimulatory factor is probably inactive in the conjugated state. Together, our data and those of Strand and Marver suggest that the stimulator may be a compound of small molecular weight, normally conjugated and protein bound. The inhibitory factor, on the other hand, appears to be a protein or a substance requiring tight binding to a protein for activity.

There have been no previous reports of substances in human sera that inhibit liver cell porphyrin formation. Sardesai and Orten (21) found an inhibitor of porphyrin formation by acetone powder preparations of beef liver in the plasma of dogs. Like the inhibitory factor we have observed in human sera, the canine factor was heat labile.

Substances that inhibit erythroid heme synthesis in human sera have been reported. The sera of certain patients with red cell aplasia (22) have been found to 
contain gamma globulin inhibitors of erythropoiesis which have recently been shown to act directly on erythroid cells $(23,24)$. It is possible that the inhibitor of heme synthesis in erythroid cells, and the inhibitor of porphyrin accumulation in hepatic cells (the latter also associated with the gamma globulin fraction of sera) may be related. Inhibitors of erythropoietic heme formation have also been reported in sera from individuals at high altitudes (25), newborn babies (26), anemic rats (27), hypertransfused rats (28), and in homogenates of rabbit liver, kidney, and spleen (29); however most have not been characterized. The last factor mentioned (29) was heat stable, which distinguishes it from the serum inhibition of porphyrin formation we have observed.

The pronounced inhibition of porphyrin formation by post partum sera is not, in all likelihood, attributable to prolactin, since human prolactin falls to prepregnant levels within 1 or 2 wk post partum (30), while strong inhibition of porphyrin accumulation persisted for at least $6 \mathrm{wk}$ post partum, in both lactating and nonlactating women. Moreover, bovine prolactin added to liver cell cultures did not inhibit porphyrin formation. The possibility that the serum factor that inhibits porphyrin formation may be an antibody whose production is increased post partum must be considered in light of the association of inhibitory activity with the serum gamma globulins. Elevated levels of IgM in sera of several post partum women have been reported (31). The processes occurring during uterine involution in humans are not well understood, and it is also possible that the inhibitory factor may be a myoglobin derivative or another compound produced as a result of uterine involution.

Post partum sera inhibited porphyrin formation in control cultures, inhibited the stimulation of porphyrin formation by AIA and other drugs, and inhibited activity of ALAS. They also caused some inhibition of the conversion of ALA to porphyrins, indicating that the inhibitory effect was not exerted solely at the level of ALAS. The inhibitory factor could result in inhibition of porphyrin formation by: $(a)$ directly affecting both ALAS and a subsequent step in porphyrin biosynthesis, $(b)$ binding to both ALA and chemical inducing agents, or $(c)$ affecting cellular metabolism in a way that only indirectly results in alteration of porphyrin formation. Whatever their mode of action may be, the serum factors studied resulted in gross alterations of porphyrin formation by hepatic cells. Since the factors have the capacity to modify heme biosynthesis, their occurrence in serum would seem to have clinical implications.

More than 200 chemical agents are known which stimulate hepatic porphyrin or heme formation or both $(2-8,32)$. Normal individuals may develop altered ca- pacity to metabolize drugs as a consequence of exposure to such agents, while certain genetically susceptible individuals, such as porphyrics, may develop severe clinical symptoms. The factors involved in the normal and abnormal regulation of hepatic heme formation are not yet well understood. The serum component that inhibits porphyrin formation may modulate the effect of inducers of ALAS present in the circulation in excess and thus reduce increases in porphyrin formation in response to the drugs and chemicals to which all people are commonly exposed.

The number of porphyric subjects studied here was too small to draw conclusions about the role of the factors in the porphyrias. Although stimulatory activity appears to be increased in sera from patients with both AIP and PCT, high levels of stimulatory activity and clinical manifestations are not always related. Although a substance with the capacity to inhibit porphyrin formation could be detected in the sera of most porphyrics we studied, two subjects with AIP and three with PCT seemed to lack the inhibitory component. It is possible that porphyrias are heterogeneous with respect to occurrence of the stimulatory and inhibitory factor and that the absence of the inhibitory factor may play a pathogenetic role in certain patients with the disorders. A study of the effect on porphyrin formation of serum from relatives of porphyria patients might show whether the occurrence of the factors was genetically determined and might aid in the understanding of the biochemical phenomenology of the porphyrias. It is also possible that a component in serum that can inhibit porphyrin formation may eventually prove useful in the therapeutic management of certain cases of porphyria.

\section{ACKNOWLEDGMENTS}

We thank Judith Fitzpatrick, Jan Curry, and Enid Stern for their valuable technical assistance.

This work was supported by U. S. P. H. S. Grant HR 04313, Special Fellowship FO 3 HD 40904, American Cancer Society Award BC-98, and New York City Health Research Council Grant U-2286.

\section{REFERENCES}

1. Kappas, A., C. S. Song, S. Sassa, R. D. Levere, and S. Granick, 1969. The occurrence of substances in human plasma capable of inducing the enzyme $\delta$-aminolevulinate synthetase in liver cells. Proc. Natl. Acad. Sci. U. S. A. $64: 557$.

2. Granick, S. 1966. The induction in vitro of the synthesis of $\delta$-aminolevulinic acid synthetase in chemical porphyria. A response to certain drugs, sex hormones and foreign chemicals. J. Biol. Chem. 241: 1359.

3. Granick, S., and A. Kappas. 1967. Steroid induction of porphyrin synthesis in liver cell culture. I. Structural basis and possible physiological role in the control of heme formation. J. Biol. Chem. 242: 4587.

4. Racz, W. J., and G. S. Marks. 1972. Drug-induced 
porphyrin biosynthesis. IV. Investigation of the differences in response of isolated liver cells and the liver of the chick embryo to porphyria-inducing drugs. Biochem. Pharmacol. 21 : 143.

5. Kappas, A., C. S. Song, R. D. Levere, R. A. Sachson, and S. Granick. 1968. The induction of $\delta$-aminolevulinic acid synthetase in vivo in chick embryo liver by natural steroids. Proc. Natl. Acad. Sci. U. S. A. 61: 509.

6. Rifkind, A. B., P. N. Gillette, C. S. Song, and A. Kappas. 1970. Induction of hepatic $\delta$-aminolevulinic acid synthetase by oral contraceptive steroids. J. Clin. Endocrinol. Metab. 30: 330

7. Wada, O., Y. Yano, G. Urata, and K. Nakao. 1968. Behavior of hepatic microsomal cytochromes after treatment of mice with drugs known to disturb porphyrin metabolism in liver. Biochem. Pharmacol. 17: 595.

8. Rifkind, A. B., P. N. Gillette, C. S. Song, and A. Kappas. 1973. Drug stimulation of $\delta$-aminolevulinic acid synthetase and cytochrome $\mathrm{P}-450$ in vivo in chick embryo liver. J. Pharmacol. Exp. Ther. 185: 214.

9. Koskelo, P., A. Eisalo, and I. Toivonen. 1966. Urinary excretion of porphyrin precursors and coproporphyrin in healthy females on oral contraceptives. Br. Med. J. $1: 652$.

10. Marver, H. S., and R. Schmid. 1972. The porphyrias. In Metabolic Basis of Inherited Disease. J. B. Stanbury, J. B. Wyngaarden, and D. S. Fredrickson, editors. McGraw-Hill Book Co., New York. 3rd edition. 1087.

11. Goldberg, A., M. R. Moore, A. D. Beattie, P. E. Hall, J. McCallum, and J. K. Grant. 1969. Excessive urinary excretion of certain porphyrinogenic steroids in human acute intermittent porphyria Lancet. 1: 115.

12. Kappas, A., H. L. Bradlow, P. N. Gillette, and T. F. Gallagher. 1972. Studies in porphyria. I. A defect in the reductive transformation of natural steroid hormones in the hereditary liver disease, acute intermittent porphyria. J. Exp. Med. 136: 1043.

13. Poland, A., and E. Glover. 1973. 2,3,7,8-Tetrachlorodibenzo-p-dioxin: a potent inducer of $\delta$-aminolevulinic acid synthetase. Science (Wash. D. C.). 179: 476.

14. Kissane, J. M., and E. Robins. 1958. The fluorimetric measurement of deoxyribonucleic acid in animal tissues with special reference to the central nervous system. J. Biol. Chem. 233: 184.

15. Levęre, R. D., F. Swerdlow, and M. R. Garavoy. 1971. Measurement of human plasma hemoglobin by difference spectrophotometry. J. Lab. Clin. Med. 77: 168.

16. Albert, A., J. Kobi, J. Leiferman, and I. Derner. 1961. Purification of pituitary gonadotropin from urine of normal men. J. Clin. Endocrinol. Metab. 21: 1.

17. Müller-Eberhard, H. J. 1960. A new supporting me- dium for preparative electrophoresis. Scand. J. Clin. Lab. Invest. 12: 33

18. Lowry, O. H., N. J. Rosebrough, A. L. Farr, and R. J. Randall. 1951. Protein measurement with the Folin phenol reagent. J. Biol. Chcm. 193: 265.

19. Van Hall, E. V., J. L. Vaitukaitis, G. T. Ross, J. W. Hickman, and G. Ashwell. 1971. Immunological and biological activity of HCG fo!lowing progressive desialyation. Endocrinology. 88: 456.

20. Strand, L. J., and H. Marver. 1970. Determination of $\Delta$-aminolevulinic acid synthetase (ALA-S) in cell culture: naturally occurring inducers in normal human plasma. Clin. Res. 18: 345.

21. Sardesai, V. M., and J. M. Orten. 1965. Role of a plasma factor in porphyrin biosynthesis. Proc. Soc. Exp. Biol. Med. 120: 552 .

22. Krantz, S. B., and V. Kao. 1967. Studies on red cell aplasia, I. Demonstration of a plasma inhibitor to heme synthesis and an antibody to erythroblast nuclei. Proc. Natl. Acad. Sci. U. S. A. 58: 493.

23. Zaentz, S. D., and S. B. Krantz. 1972. Demonstration of cytolytic antibody specific for erythroblasts in pure red cell aplasia (PRCA). Clin. Res. 20: 504.

24. Zalusky, R., E. D. Zanjani, A. S. Gidari, and J. Ross. 1973. Site of action of a serum inhibitor of erythropoiesis. J. Lab. Clin. Med. 81: 867.

25. Reynafarje, C., J. Ramos, J. Faura, and D. Villaviencio. 1964. Humoral control of erythropoietic activity in man during and after altitude exposure. Proc. Soc. Exp. Biol. Med. 116: 649.

26. Skjaelaaen, P., and S. Halvorsen. 1971. Inhibition of erythropoiesis by plasma from newborn infants. Acta Paediatr. Scand. 60: 301.

27. Molinari, P. F., F. F. Menninger, Jr., and H. Rosenkrantz. 1970. Detection of an inhibitor of hemoglobin synthesis in rat plasma. J. Lab. Clin. Med. 76: 466.

28. Whitcomb, W. H., and M. Z. Moore. 1965. The inhibitory effect of plasma from hypertransfused animals on erythrocyte iron incorporation in mice. J. Lab. Clin. Med. 66: 641.

29. Erslev, A. J., and L. A. Kazal. 1968. Inactivation of erythropoietin by tissue homogenates. Proc. Soc. Exp. Biol. Med. 129 : 845.

30. Hwang, P., H. Guyda, and H. Friesen. 1971. A radioimmunoassay for human prolactin. Proc. Natl. Acad. Sci. U. S. A. 68: 1902.

31. Gusdon, J. P., Jr. 1969. Fetal and maternal immunoglobulin levels during pregnancy. Am. J. Obstet. Gynecol. 103 : 895.

32. Conney, A. H. 1971. Environmental factors influencing drug metabolism. In Fundamentals of Drug Metabolism and Drug Disposition. B. N. LaDu, H. G. Mandel, and E. L. Way, editors. The Williams \& Wilkins Co., Baltimore. 253. 